\title{
Hõimlane verejõe tagant: Saami muinaslood tootempõhjapõdrast. II
}

\author{
$\underline{\text { Enn Ernits }}$
}

\subsubsection{Meheiga}

"Mäetaguste" eelmises numbris käsitlesime saamide tootempõhjapõdra sündi ja lapsepõlve (vasikapõlve) ning lahkumist ema juurest (4.1.1). Seekord alustame loo kangelase täismeheea tähtsündmusest - naisevõtust, millele järgnes aastate möödudes teine perekonnast lahkumine.

\subsubsection{Naisevõtt}

Kujutelm inimese ja looma vahelisest abielust lähtub totemismist (Kostjuhhin 1987: 45). Meandashi naisevõtu-lood võib jagada kolmeks alatüübiks. Esimesest teab allakirjutanu kolme, teisest kahtteist, kolmandast aga kõigest kaht teisendit. Esimesele alatüübile on tunnuslik verejõe ületamine, teisele kosilaste ( kaaren, hüljes ja põhjapõder) kolmik, kolmandale aga söögitegemise lubamatu jälgimine mõrsja poolt.

\subsection{Esimeses alatüübis}

naib põhjapõder ise või talle võetakse verejõe tagant naiseks eide-taadi kolmest tütrest noorim.

Esimene jutt (kokkuvõte vt $\underline{4.1 .1}$ )

V. Tsharnoluski (Tsharnoluski 1965: 54) kirjutas:

Küsimusele, mida tema [= loo jutustaja Pjotr Sarvanovi] kodukandis Imandra järve ääres Monntsh-gubas teatakse meandashitest, vastas ta küsimusega: "Kas mientushitest?" "Jah, mientushitest," laususin pead noogutades, nagu teadnuksin, kes need sihukesed on. Pjotr elavnes ning vastas meie poole pöördudes: "Noh, kes need siis on? See on nagu tõestisündinud lugu... Ma näen neid elavatena, sellistena, nagu nad on. Kas tahate, ma jutustan neist? Ei, see pole muinasjutt, vaid lõvt $\underline{* 15}$ - tõestisündinud lugu, nii nagu vanamehed on seda rääkinud."

Ning ta jutustaski meile huvitava mü̈di.

Väga põnev on tulevase pereelu tarbeks koja rajamine. Koda pole sugugi tavaline. Selle sõrestik on tehtud põhjapõdraluudest: jäsemeluud tugedeks, roided katuselaudadeks, ase aga kaetud pehme põhjapõdranahaga. Koda toetub põhjapõdrajalgadele, ehitamisel kasuti selgroolülisid ja roideid. Sama motiiv esineb ka üheksandas ja kümnendas jutus: mõlemal juhul on tegemist juba abielus oleva põhjapõdraga.

Põhjapõdrakoja sarnasust "Kalevalas" kirjeldatuga, nagu ka saarmaks moondumist, on märganud E. Autio (Autio 1993: 82). Eeposes kõlab huvipakkuv koht järgmiselt: 
Kõrvalsein on siililuista, pärasein on põdraluista, uksesein on ahmiluista, päälispuu on pässuluista. (Kalevala XXI: 159-162)

Soome ja saami ainese põhiline erinevus seisneb selles, et ühel juhul on hoone valmistatud erinevate loomade luudest, teisel aga ainuüksi põhjapõdra omadest. "Kalevalas" nimetatud värsid kõnelevad Põhjala pulmade mõrsjakodust, kuid A. Turuneni sõnaraamatu andmeil on need esialgu kuulunud Toonela toa kirjelduse juurde (Turunen 1981: 234). Meandashite verejõetagune maailm ja musta jõe taga asetsev Toonela on semantiliselt identsed, seepärast tasuks elamute seost täiendavalt uurida, liiati, kui mõlemad on abieluga ühenduses.
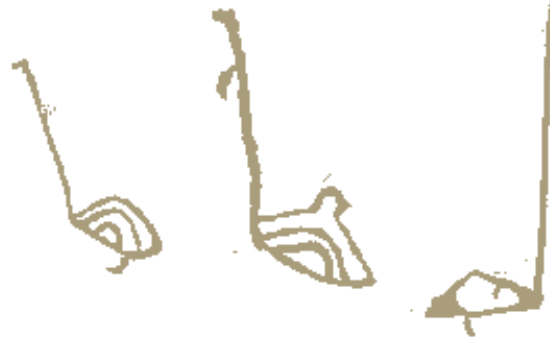

Müütilise põhjapõdra maja meenutab põhjapõtra, milles avalduvad saamide kujutelm mikrokosmosest ja skeletiga seonduvad uskumused. Põhjapõdrakoja läveks olid kaelalülid. Tundub, et kaela semantikale pole soome- ugri usundiloos pööratud küllaldast tähelepanu. Kael, kergesti haavatav kehaosa, on ligipääsukohaks hinge juurde ning vajab sellisena eriti kaitset. Kael pole ainuüksi mugav koht ripatsite kandmiseks, vaid need ka kaitsevad teda. Usutavasti ei ole läänemeresoome kael luksuslaen, nagu tavatsetakse arvata (saami keeli see ei puuduta), vaid tabulistel põhjustel balti algkeelest omaks võetud sõna. Äänisjärve kaljudele on nooremal kiviajal raiutud palju luigekujutisi, mille kael on kerest mitu korda pikem. Seegi osutab kaela tähtsusele muistsetes kujutelmades. Lävi on ühelt poolt valvatavaks piiriks mikro- ja makrokosmose vahel, teisalt aga neid ühendav hooneosa. Kael on valvatav piir sise- ja välisilma vahel, mis ühendab pead kerega. Tõenäoliselt sellest tulenebki idee künnise valmistaniseks just kaelalülidest. Rituaalse söömingu käigus anti esimene kaelalüli meestele, seitsmes aga neidudele (Tsharnoluski 1966: 308), mis näitab nende erinevat semantilist kaalu.

Pühaseaseme ümbritses põhjapõder rinnalülidega. Rinnakorv on südame ja hinge asupaik, turvalisem ja puhtam kui magu ja sooli sisaldav kõhuõõs. Näib, et Soome saamidki on kõige tähtsamateks luudeks pidanud selgroogu ja rinnakut (Itkonen 1946: 246). Ilmselt seepärast, et luud säilivad suhteliselt paremini, arvatakse, et neisse jääb püsima osa hingeainest (Paulson 1958: 238). Luud seonduvad tõenäoliselt esivanematega; kollektiivse söömingu käigus oli nii saamidel kui ka näiteks turgi rahvastel loomakeha jagamisel kindel kord. Oletatakse, et selle alusprintsiibiks on mõlema struktuuri - sugukonna ja ohvrilooma identsuse demonstreerimine (Tradicionnoe mirovozzrenie 1990: 39, 42, 43).

Lugedes Tsharnoluski kirjapanekut verejõest, mille laineteks on kopsud ja kivideks maksad, tekkis siinkirjutajal esialgu kahtlus selle ehtsuses. Ent 1994. aastal ilmunud J. Sergejeva artikkel hajutas selle. Maksa võrdlus kividega on tabav. Veest libedad kivid ja maksa siledus! Anatoomina kujutlen, et näha on selle vahelihase poole olev kumerduv pind. Uurimist vääriks aga nimetatud elundi osa saami uskumustes, sest teadaolevalt näiteks mesopotaamia ja etruski targad ennustasid maksa ehituslike ja haiguslike iseärasuste põhjal riigi ja valitsejate tulevikku (vt lähemalt Ernits 1990). 
Erinevalt eespool käsitletud teisendist on käesolevas loos põhjapõder noor ja vallaline (see ongi ehk algsem variant) ning ta ei kosi endale naist ise, vaid selle naidab ta ema. Selleks ujub ema üle verejõe inimeste maailma, eide-taadi juurde. Neil on, nagu esimeseski teisendis, kolm tütart, kellest kaks ei kõlba moraali poolest kuhugi. Nad pole sõnakuulelikud, nad täidavad ülesandeid hooletult ning isegi varastavad. Kõige kurja palgaks on surm. Käesolevas loos muudetakse nad elututeks, hingetuteks kivideks, mille poolest Lapimaa on teatavasti rikas. Niisiis ei võinud taolistest nurjatutest saada põhjapõdrarahva esivanemaid. Ka ei osanud vanemad tütred loitse ning pääsesid seetõttu teispoolsusesse suuri vaevu. Sealgi näitasid nad oma pahameelt põhjapõdrapoegade suhtes. Vist tulekski arvata, et need võisid olla naisevõtu eas nooruki nooremad õed-vennad, kuigi lugu ise selle koha pealt vaikib. Eelmises loos olid põhjapõdravasikad muide lesestunud põhjapõdra lapsed!

Anname jutujärje P. Sarvanovi kätte:

Läkski Meandash-neiu laia maailma oma pojale naist otsima. Ta moondus põhjapõdralehmaks ja ujus üle Meandash-jogki - verejõe. Selles on kopsudest lained ja maksadest kivid. Ta ületas jõe ja pistis jooksu. Jooksis, jooksis, kuni jõudis inimese koja juurde. Pööras end kanna peal ringi ning astus sureliku naisena kotta. Astus sisse, võttis kammed *16 jalast ja küsis:"Kes tütardest tuleb mu pojale naiseks?" Taadil, kes selles kojas elas, oli kolm tütart. Vanem neist lausus: "Mina tulen!"

"Noh, kui sa tuled naiseks," ütles Meandash-neiu, "siis pane mu kammed kuivama. Tee nad ilusasti korda ja kuivata ära," käskis ta ning väljus kojast.

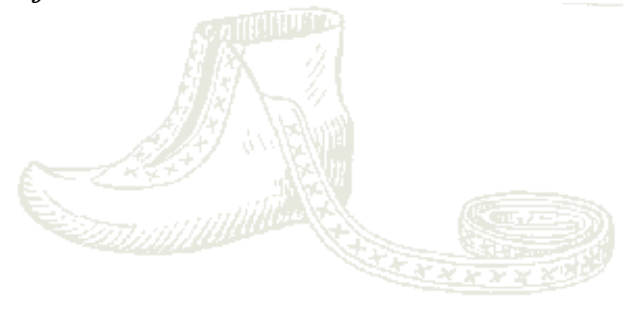

Kammed polnud tavalised. Seest olid nad puoidast - rasvast, sisetallad aga kõige õrnemast, kõige maitsvamast rasvast - tonk-puoida'st ${ }^{*} 17$. Meandash-neiu magas seal hommikuni, ärkas siis üles ja lausus vanemale tütrele: "Too minu kammed ja siledaks tehtud sisetallad siia." Ent neiu oli rasva kammedest nahka pistnud! Rasva asemele oli ta neisse pannud rohtu, sisetallad teinud aga koredast lambaheinast. Ta tõi jalatsid Meandash-neiu ette ja sõnas: "Torka nad jalga!"

Meandash-neiu kängitses, kuid kammedes oli rohi ning sisetallad polnud omad! Ent ta ei lausunud sõnagi.

Meandash-neiu ja taaditütar asusid koduteele. Jõudsid peagi Meandashi-jõe äärde.

Meandash-neiu küsis:

"Kuidas, sa, Peit'-oll'ke - Mahalangenud Sukk*18, Meandashi-jõest üle saad, sest lained on kopsudest ja kivid maksadest."

Kuid too vastu: "Kuidas saad sina, nõnda ka mina."

Selle peale ei lausunud Meandash-neiu musta ega valget. Ta moondus põhjapõdralehmaks, ujus üle Meandashi-jõe ning jooksis siis edasi. Noorik jäi teisele kaldale. Ta hulkus sinnatänna, pidi peaaegu ära uppuma, kuid pääses siiski kuidagimoodi üle jõe.

Meandash-neiu jõudis koju. Koja ees jooksevad põhjapõdravasikad.

"Minge nü̈d noorikule vastu," käskis ta.

Vasikad jooksid sõrakesi klõbistades taaditütrele vastu. Ent tütrel oli kepike käes. Sellega lõi ta kõigil ninast vere välja. Meandash-paarrn'id pagesid koju tagasi. 
Viimaks jõudis ka noorik meandashite koja juurde. Avas ukse, ise aga räägib: "Meandashite kotta astun, üle tsheäppat-läve *19 sammun. Puhaskoht on rinnalülidega ääristatud! Sammasteks aga põhjapõdrajalad! Katus aga nahkadest!"

Siis lausus Meandash-neiu: "Muutu kiviks!"

Noorik muutuski kiviks.

Seevastu noorem tütar kuivatas korralikult tulevase ämma jalanõud. Ta polnud päris tavaline inimene, erinevalt oma vanematest õdedest oskas ta loitsida. Sõna jõul võib ületada piiri siin- ja sealpoolse maailma vahel:

Kuiva, kuiva, Meandashi-jõgi!

Kopsudest lained, maksadest kivid.

Verejõgi!

Seejuures näris neiu lepakoort ja sülitas mähka verejõkke. Lepp on vere hüpostaas: Kui veisel oli kusi verest punane, siis öeldi mõnel pool Eestis ajas leppa (Viires 1975: 100). Lepapuud peeti muiste punaka mäha tõttu verd sisaldavaks; seepärast muutus ta soome-ugri rahvastel soome teadlase T. Lehtisalo väitel pühaks hingepuuks (Lehtisalo 1934).

Verekusesuse korral toimiti analoogiamaagias valitseval põhimõttel similis simili gaudet - sarnane meeldib sarnasele. Nii näiteks on eesti ja vadja rahvaveterinaarias tuntud võtteks lepapuust vaia tagumine masse kohal, kuhu punakusehaige veis urineeris (Viires 1975: 100). Mõlemad rahvad uskusid, et nimetatud haiguse põhjustas see, kui leppälintu (mingi punane linnuke) looma kõhu alt läbi lendas. J. Sergejeva andmeil on lepp saamide maagiline puu, mille koorekeedist kasutati paljudes rituaalides (Sergejeva 1994: 167-168). Juba XVII sajandist pärineb teade, et süljega segunenud lepamämmi tarvitati shamaanitrummi valmistamisel. Sarnast meetodit kasutasid muide ka evengid (vt Kosmenko 1993: 35). Lepakoore närimist ja küti ülepritsimist süljega tavatseti kasutada karupeiedel (Krohn 1906: 179). Meenutagem, et saami metsaisand oli nime poolest Leeaibe-olmmai - 'lepainimene'.

Käesolevaski loos leidub viiteid analoogiamaagiale: verd sai vaid lepaga (= vere aseainega) kuivatada, mispeale "Meandash-jogk muutus kuivemast kuivemaks" ning inimesetütar võis jalgsi ületada jõesängi. Seejärel haukas ta jälle lepakoort, sülitas mähka vette ja laulis:

Voola, voola, Meandashi-jõgi:

Kopsudest lained, maksadest kivid.

Verejõgi!

Sama toiminguga taastati endine olukord ning verejõgi hakkas vanaviisi voolama.

Lepaoksa närimine ja mäha vette sülitamine jõe ületamisel esineb muide ka ühes Suönnijeli (soome Suonikylä) koltalt noteeritud loos, milles ema otsib naist koerinimesele (Itkonen 1931: 171).

Taadi noorem tütar hellitas põhjapõdravasikaid ja sidus neile punased kaleviribad kõrvadesse. Sellega tunnistas ta nad omadeks. Punane värvus seostub verega, selle kaudu sugulastega ning on püha. Oma-kategooria ilmseks tõendiks verejõe käsitlemisel on kildinisaami kujutelm, milles unes 
nähtud veri tähendab sugulase külaskäiku (Szabò 1967: 44--45). Kõrva pidasid saamid ka hinge asupaigaks (Tsharnoluski 1972: 112) ning see kuulus saamidel ohverdatavate kehaosade hulka (Leem 1771: 215-216). Lisaks on teada, et Akkalas olid kuhjas lebavatele põhjapõdrasarvedele seotud punasest riidest lindikesed ja kolmnurgad ning sarvede ohverdamisega taotleti edukat jahti (Tsharnoluski 1966: 308).

Jälgigem nüüd müütiliste esivanemate elukäiku P. Sarvanovi suu läbi:

Rõõmsalt ema juurde naasnud, hüüavad vasikad: "Näe, kuidas noorik võttis meid vastu! Ta sidus meile punased kaleviribad kõrva külge."

Meandash-neiu vastu: "Siis on hästi."

Peatselt naasis Meandash-paarrn jahilt.

"Kus on mu naine?" küsis ta ning Meandash-neiu vastas, et noorik ootab teda soo serval. Meandash-paarrn pistis põhjapõdrapullina jooksu. Ta kiirustas mõrsjat vaatama. Piiga istub soo ääres ja laulab:

"Ennäe, ta jookseb! Ennäe, ta jookseb,

Meandash-paarrn, meandashi poeg!"

Meandash tegi tüdruku ümber päris suure ringi ja naasis ema juurde. Ema küsib: "Kas sa oma mõrsjat nägid?"

"Nägin," vastas Meandash-paarrn. - "Kas sa suudad temaga koos elada?"

Meandash-paarrn vastu: "Käisin nii päri- kui ka vastutuult. Jall' voai *20 - võin elada."

Meandash-paarrn ehitas endale uue koja. Ta ilmus tüdruku ette kauni noormehena ja võttis ta endale naiseks."

Alles Meandashi lahkumise lugude käsitlemisel selgub, miks põhjapõder pidas tuult hoolega silmas.

J. Sergejeva mainib sood Meandashi nimega seonduvalt (vt $\underline{2}$ ), eelnevas jutukatkendis kulmineerub just abiellumislugu soo servas. Selle juhuslikkus või mitte juhuslikkus on raskesti tõestatavad. Osutame J. Sergejeva vahendusel Siberi rahvaste mütoloogia uurijale A. Anisimovile, kes on käsitlenud kosmilist sood sölkuppidel ja evenkide soo-sõna tuletist dätur, mis tähendab kosmilise hõimujõe läbi kolme maailma voolavaid harusid. Sölkupi müüdis kõneldakse kahest poolinimesepoolpõhjapõdrakujulisest esiemast, kes elavad maailmapuud ümbritsevas kosmilises soos, kust saavat alguse põhjapõtrade sugu.

\section{Kuues jutt}

"Skazka o dikom olene". A. Jashtshenko, 1887 < Imandra kant, Tshukksuöl(?). Avaldatud vene keeles Jashtshenko 1892: 34-35; Kert 1980: 202-203 (nr 130).

Naisevõtt. Lesestunud põhjapõder kosis saamiks moondunult esialgu sureliku saami vanema, hiljem keskmise, siis noorema tütre.

Verejõe ületamine. Põhjapõder naasis üksi metsa kaudu koju. Vanem tütar tuli põhjapõdra koju ületades kopse täis oleva verejõe saarmana ujudes. Noorem tütar ületas jõe loitsinud enne verejõe kuivaks.

Tütarde käitumine. Vanem ja keskmine tütar ei hoidnud põhjapõdra lapsi. Nad ei hoolinud sellest, et asemenahad oleksid kuivad, kuna nad ei sallinud, et mees on põhjapõder. Noorem tütar hellitas põhjapõdra lapsi ja punus neile pärjad sarvedesse.

Tütarde saatus. Vanema ja keskmise tütre puskis põhjapõder surnuks. Noorema tütre võttis ta aga endale naiseks. Neil sündis laps. 
Lahkumine naise ja laste juurest. Laps pissis asemele. Põhjapõder põgenes, lapsed kannul. Ema reageering. Ema hoiatas lapsi kavala laplase eest ning soovitas õigele kütile oma süda ette asetada, et ta saaks looma sarvega tappa.

Selles jutus võetakse naine saamide maalt verejõe tagant. Moraalsete omaduste poolest sobib vaid noorem õdedest põhjapõdrale naiseks. Naisevõtu-loo ülesehitus on muinasjutupärane: kositakse järgemööda kolme õdet, kuid naiseks kõlbab siiski üksnes noorim. Vanemad õed ei taha millegipärast kohaneda põhjapõdra tavadega. Tagajärjeks on hukkumine.

Käsitletava teisendi põhiliseks iseärasuseks on asjaolu, et põhjapõder on lesk ning tal on esimesest abielust lapsed, samuti põhjapõdrad. Mehe leseksjäämist pole kirjeldatud. Loos kajastub totemistlik ja shamanistlik mõttelaad, mispuhul põhjapõdrast mees abiellub surelikuga. Ta on võimeline kosimisel inimeseks muutuma ning näib, et põhjapõdraks muutub ta taas oma kodus, kus tütred saavad teada, kes ta tegelikult on. Nad hakkavad oma meest ja tema lapsi vihkama. See on aga surmapatt. Tundub, et naisevõtulugudel on didaktiline alltekst, mille varal ilmselt õpetati tootemit surmahirmus austama.

Samuti ei hoolinud ei vanem ega keskmine tütar, et ase oleks kuiv. See motiiv on põimitud ehk ilmaasjata kaks korda jutu sisse. Tavaliselt seondub see Meandashi lahkumisega naise ja laste juurest.

Käesoleva artiklisarja pealkirjaks pole juhuslikult pandud "Hõimlane verejõe tagant". Verejõgi on midagi eriti kummalist oma kopsudest lainetega. Kui inimene või loom lamab selili, siis meenutavad kopsude teravservad ja peapoolne sagar tõepoolest laineid. Verejõgi on saami kujutelmades tavainimeste ja müütilise põhjapõdrariigi eraldajaks. Ta on piiriks elu- ja surmariigi, kaaslaste ja esivanemate vahel. Toonela mustal jõel ja Verejõel sama semantika: mõlemad on piiriks siin- ja teispoolsuse vahel.

Jutust paistab, nagu põhjapõdral polekski tegemist verejõega, sest tema jooksis koju hoopis läbi metsa. Võiksime seda tõlgendada nii, et teispoolsuse esindajal pole probleemi piiri ületamisega, ent inimeselaps ei pääse ühest maailmast teise nii lihtsalt. Vanem tütar moondus selleks nobedaks veeloomaks saarmaks. Meenutagem, et eeposes "Kalevala" tegi Toonelast pagedes sarnase muundumise läbi igipõline shamaan Väinämöinen (Lönnrot 1958: 107 August Annisti tõlkes):

Oskas muuksi muutuneda, ruttu teiseks teiseneda: läksi mustana mereje, saarmana rohu siseje (Kalevala XVI: 369-372).

Lisame, et saarma müütilisusele osutab tema hiigelkujutis Äänisjärve kiviaegsete kaljuraiendite seas Besi neemel. Oma eluviisilt sobib see hinnaline karusloom müütiliseks vahendajaks eri universumisfääride vahel. Ta ujub vees ja kõnnib kuival maal, võttes mõnikord kahel jalal seisva palvetaja poosi. Võime pidada saarmast ambivalentseks tegelaseks, kelleks tüdruk, saami taadi vanem shamaanist tütar muutus. 
Noorem tütar oli samuti shamaan: ta oskas loitsida. Loitsu tohutu võim suutis jõe kuivatada, kuigi vajadusele vastavalt ainult üürikeseks ajaks! Ironiseerime siinpuhul, et mitshuurinlased ei oleks sellega loodust hävitamata toime tulnudki.

Verejõe ületamist esineb ainult kolmes teisendis (kahes Imandra kandist registreeritud ja ühes kildini loos). Kahjuks on andmed informantide kohta puudulikud, mis ei võimalda leviku kohta teha mingeid olulisi järeldusi.

\section{Seitsmes jutt}

J. Sergejeva, $1990<$ Lazar Jarovlev. Kildin, Lujaur. Avaldatud saami ja soome keeles Sergejeva 1994: 167 (katkend).

Verejõe ületamine. Meandashi poolt mõrsjaks valitud tüdruk ületab verejõe loitsides.

Lugu on üles kirjutatud meie päevil ning katkendi järgi otsustades näib sarnanevat eelmisega. Võimalik, et ka eelmiste müüditeisendite jutustajaks võis olla kildinlane. Katkend sisaldab kaks saamikeelset osist:

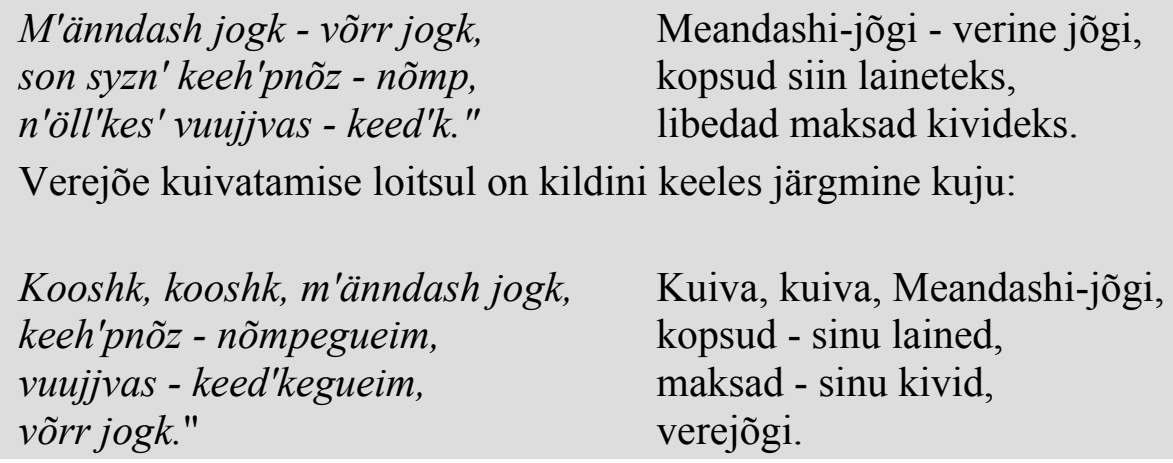

\subsection{Teises alatüübis}

kosis kaaren (eide)-taadi vanema, hüljes keskmise ja põhjapõder noorema tütre. Eite-taati läksid tütardele külla ja nägid, et ainult põhjapõdraga abiellunu elab õnnelikult. Esimese alatüübiga on ühine vaid see, et põhjapõdra naiseks saab eide-taadi (sureliku saami) noorem tütar.

\section{Kaheksas jutt}

"Olen' dikar' [I]". V. Tsharnoluski, 1927(?) < Maksimõtsh. Akkala, Tshurozero ääres. Avaldatud vene keeles V. Tsharnoluski 1972: 114-117.

Naisevõtt. Kaaren, hüljes ja põhjapõder kosisid inimeseks moondunult vastavalt taadi-eide vanema, keskmise ja noorema tütre.

Külaskäigul. Taat külastas järjepannu oma tütreid. Vanemal tütrel oli kaaren silma peast välja nokkinud. Keskmisel tütrel oli hüljes sõrmed ära närinud. Ainult noorem tütar elas põhjapõdraga õnnelikult. Taat elas mõnd aega noorema tütre juures, siis naasis ta koju ja tõi eidegi sinna elama. Lahkumine naise ja laste juurest. Eit riputas täispissitud naha ukse ette kuivama. Jahilt naasnud põhjapõder põgenes igaveseks tundrusse, lapsed vasikatena kannul. Sellest ajast peale elavad inimesed ja põhjapõdrad eraldi.

Ema reaktsioon. Ema kutsus lapsi tagasi, kuid sai vastuseks, et neid tõmbavad vastupandamatult enda poole tundrud ja metsad. Seejärel kutsus ema oma noorimat last, pakkudes talle rinda. Ent ka see keeldus tulemast. 
V. Tsharnoluskil leidub kaks samanimelist lugu: üks Akkalast, teine Turjast (vrd XIII jutt). Akkala teisend on Meandashi naisevõtu teisele alatüübile iseloomulik esindaja, kuid kosimismotiiv on seal väga lühike.

Anname sõna jutustajale, kelle ees- ja perekonnanimi ning vanus jäävad meile praegu teadmata:

Elasid taat ja eit. Elasid, elasid ning sündis neil kolm tüdrukut. Tütred said täisealisteks ning neist said neiud. Vaat saabus aeg, tulid peigmehed neile kosja.

Üks oli kaaren, teine hüljes, kolmas põhjapõder, ei kodupõhjapõder, vaid see, kes rändab tundras ja mägedes, nimelt metsik põhjapõder.

Kaarnast väimees tuli mererannikult, põhjapõder aga jooksis kohale metsast, tundrust, kaugelt mägiselt maalt. Eit oli mere kandist, ta tahtis väga anda oma noorema tütre kaarnast peigmehele. Ent taat oli põhjapõtrade soost, metsa poolt inimene. Ta tahtis oma noorema tütre anda põhjapõdrale mehele. Nõnda ta ka tegi. Selle pidas eit meeles.

Andsid vanakesed oma tütred mehele ja hakkasid üksi elama.

Vanemate päritolu käsitlemine meenutab üht "Meandashi naisevõtu" tundmata päritolu lugu (vt XVII jutt). J. Sergejeva oletab käsitletava alatüübi puhul, et kolm loomkosilast väljendavad kolme ilmasfääri: kaaren taevast, hüljes vett ja põhjapõder maad; seega osutavat see looduse hingestamisele ning usule veresugulusele inimese ja loomade vahel (Sergejeva 1994: 164).

Siinkirjutaja meelest pole välistatud, et kolm tegelast võivad väljendada eri tootemeid. Käesolevast teisendist selgub, et vanemad olid eri hõimudest: isa tootemiks oli põhjapõder, emal aga kaaren. Tehti nii, kuidas peremees tahtis, mis ei meeldinud muidugi naisele. Kaaren on muide peategelane ka Siberi ja Ameerika rahvaste mütoloogias (vt Meletinski 1979).

Vanemate külaskäiku oma laste juurde on kirjeldatud pikalt-laialt. Kõigepealt külastas taat vanemat tütart:

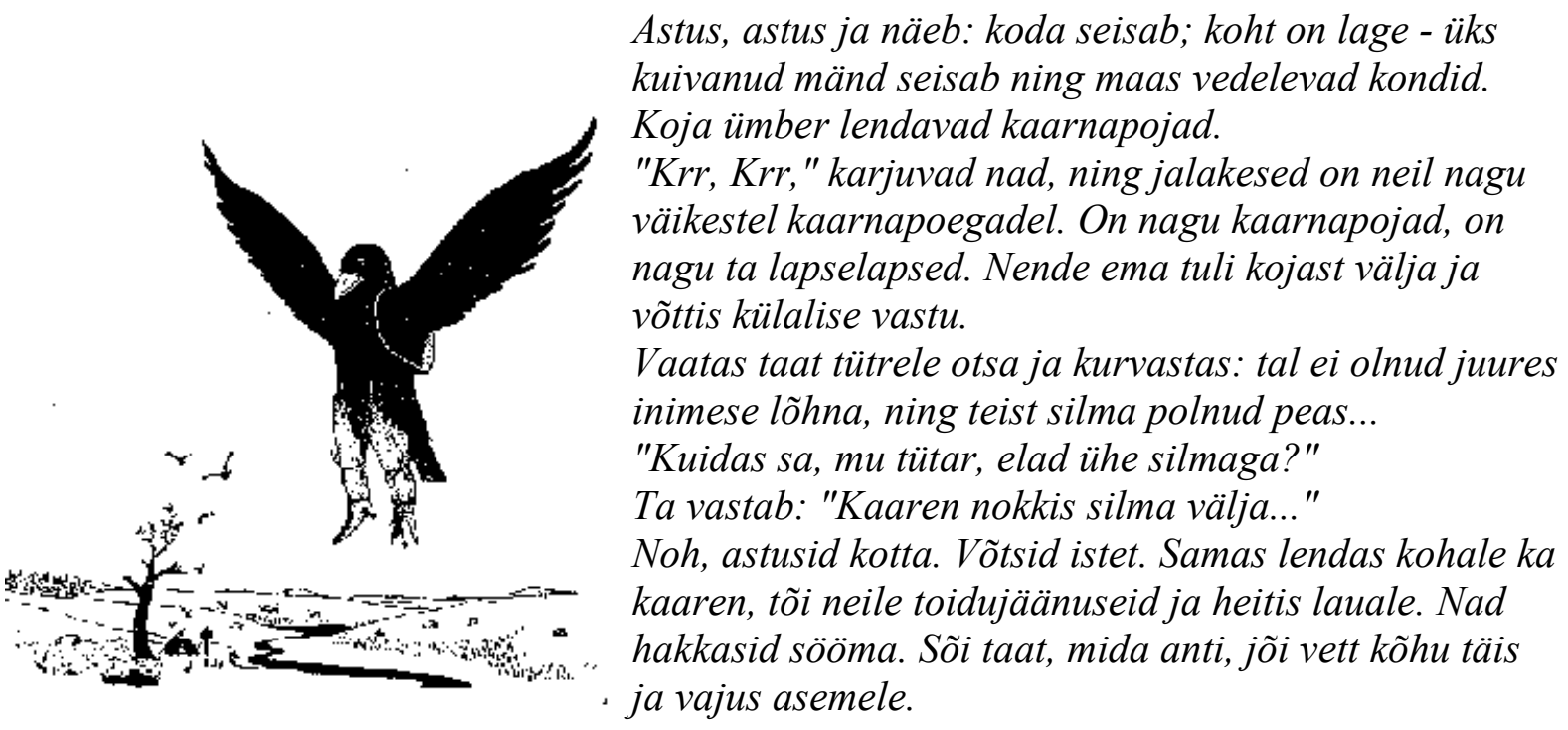


Müütides on tavaliselt tähtsal kohal mingi teekond. Ka käesolevas alatüübis külastavad eite-taati ühtejärge oma tütreid. Taat, kes ise oli põhjapõtrade soost, polnud rahul eluga kaarna peres. Seda väljendab ühelt poolt paikkonna lagedus ja kuivanud pedajas, teisalt aga korratus ja toidujäänuste söömine. Selline elulaad polnud põhjapõtradele omane. Kaaren oli mõneti vaenulik põhjapõdra tütre vastu ning naise vigaseks teinud. Ometi elasid nad koos ja sigitasid lapsi, kes olid domineeriva poole tõttu kaarnasoost.

Järgnevalt külastas taat keskmist tütart, kes oli abiellunud hülgega.

Astus, astus, kuni jõudis mere kaldale. Meri on tühi, merel pole midagi näha. Ka kallas on tühi. Lebavad vaid paljad kivid ning laine tõuseb ja vajub.

Taadil hakkas igav. Näeb lõpuks, et majake seisab. Katuselt lasevad lapsed liugu alla, veerevad küljelt küljele, laksavad loibadega vastu kõhtu: plaks ja plaks.

Tuli taat nende juurde. Nägid teda hülgepojad ja panid karjuma: "Ema, ema, vanaisa tuleb meie juurde!"

Jooksis tütar kojast välja, võtab isa vastu. Heitis taat pilgu tütre peale: see on üleni hülgerasvaga koos. Tal on juures loomahais ning üks käsi on puudu.

"Kus su käsi on jäänud, tütreke?"

"Hüljes näris käe ära," lausus see.

Noh, nad astusid kotta ja võtsid istet. Samas saabus ka hülgest peremees. Ta tõi kostiks loomarasvatükke ja-liha.

Istusid ja istusid, mälusid ja mälusid ning vajusid viimaks unne.

Ka hüljes pole taadi meelest tütrele sobiv abikaasa. Vastumeelsust väljendab taas ääretu tühjus, peale selle veel määrdumine hülgerasvaga, harjumatu toit ja väimehe vaenulikkus tütre vastu. Järgmisel päeval külastab taat oma nooremat tütart:

Vaat ta läks ja läks ning jõudis lõpuks kõrge mäe juurde. See kohake oli kaunis: ümberringi kased ja kuused, kivide vahel voolavad ojad selge veega järve. Kaljult mäetipult on näha, et kaugele ulatuvad põdrasamblikuväljad ja metsasalud.

Ümberringi laiub avarus ning tore tuul toob ninna seenelõhna.

Taat imetles ja lausus: "Meeldiv."

Ta vaatas ümberringi ja nägi, et jõekese kaldal seisab koda.

Koja ümber jooksevad lapsed, sarvekesed peas, mütsidel

tolknevad vasikanahast kõrvad. Need on ta lapselapsed. Nad

mängivad põhjapõdramängu.

Nägid taati ja pistsid karjuma: "Ema, ema, meie vanaisa tuleb meile külla."

Tütar tuli välja. Kaunina tuli ta isale vastu, parimasse

rõivasse riietunult. Ta võttis isal käest kinni ja tõi tuppa.

Taat vaatab tütart ja räägib: "Mu kõige noorem tütar, sinul on

kõige parem elu."

Tütar asetas isa aukohale, karusnahale, nahkadele. Ise 
valmistas talle värskest ja peenest rasvast lõunasöögi.

Taat sõi kõhu täis.

Siis tuli ka väimees. Väljas oli ta põhjapõder. Astus kotta

inimese kujul ja tervitas. Sihvakas ja kaunis.

Väimees küsib taadilt: "Kas meie juures on hea, isake?"

"Väga hea," vastas taat.

"Too siis, isake, ämm siia ja elage meil rahuga."

Väimees meeldis taadile; vaat elas ta mõne aja noorema tütre

juures, hakkas igatsema eide järele ja suundus koju.

Selles loos avaldub suurepäraselt oma ja võõra eristamine. Viimast iseloomustab harjumatus, halbus ja inetus, kuid oma on harjumuspäraselt hea ja ilus. Ümbrus on meeldivalt metsane, ojas voolab puhas vesi, rikkalikult on põhjapõtrade põhilist toitu - põdrasamblikku. Oma inimest austatakse: ta pannakse aukohale pehmetele nahkadele istuma. Tütar on kaunites rõivastes. Põhjapõdrast väimees on kaunis. Omade juures võib elada, mistõttu taat asus esialgu üksi, pärast koos eidega põhjapõdra perre elama. Tähelepanu äratab, et ainult põhjapõdrast väimees moondus inimeseks, teised jäid aga loomaks, mis rõhutab veelgi omasust. Kõrge mägi näib sümboliseerivat maailmakesksust, kust kõik on näha.

Lähemat käsitlust väärib põhjapõdralaste põhjapõdramäng, mis V. Tsharnoluski arvates tähistas kollektiivse jahikultuse relikti, mis sarnanevat evengi rituaalse peo ikänipkäga (Tsharnoluski 1966: $310 \mathrm{jj}$ ). Põhjapõdramängu on kirjeldanud peale äsja nimetatu juba N. Haruzin ja ajakirjanik Zinaida Richter 1925. aastal (Haruzin 1890: 340, 383). Mäng toimub kahe rühma, noormeeste/poisikeste ja neidude/tüdrukute vahel. Mõlemad panevad kõrva juurde põhjapõdrasarve, kujutades vastavalt isas- ja emaspõhjapõtru. Esimesed püüavad teistest taga ajades võitu saada. Kui tagaajamine on täies hoos, ilmub kaks-kolm meesterahvast, kes kujutavad endast vibukütte. Nad ammuvad jooksvaid "põhjapõtru" ning "nülivad" tabatuid. J. Richter kirjeldas mängu järgmiselt: "S ü g i s e 1 pühitsevad laplased erilist põhjapõdrapüha. Sel päeval ei rakendata loomi saani ette. Kõik lapi mehed suunduvad Põhjapõdrasaarele. Siin toimub midagi muistse ohvritalituse sarnast. Laplased peidavad kaasatoodud porosarved koopasse. Taadid jutustavad, et saarel toimunud muiste noormeeste võistlusmängud; nad hakanud võitlema ihualasti, põhjapõdrasarved peas. Võitja saanud autasuks kõige ilusama neiu. Pärimuse kohaselt polevat ükski naisterahvas Põhjapõdrasaarel viibinud. Tarvitses vaid naisel saarele sõitmiseks paati asuda, kui tõusis torm." (tsiteeritud Tsharnoluski 1966: 312 järgi). Usutavasti toimus meid huvitavas Meandashi-tsükli loos ka taoliseks rituaaliks valmistumine.

Koda väljendab opositsioonipaari kultuur-loodus esimest osa. Nendevaheliseks piiriks on seinad. Väljas esines põhjapõder loomahüpostaasis, kotta, kus tal naiseks oli inimlaps, ilmus ta antropomorfsel kujul. Teispoolsuses paiknes koda, kuhu taat võõrana ei oleks pääsenud, selleks pidi omainimene, meie lugudes põhjapõdra abikaasa, teed sillutama. 


\section{Üheksas jutt}

a) "Pro vorona, tjulenja i dikogo olenja". Georgi Kert, $1954<$ Anna Antonova < Maria Antonova (1900). Kildin, Teriberka. Avaldatud saami ja vene keeles Kert 1961: 158-162.

Naisevõtt. Kaaren kosis vanema, hüljes keskmise ja põhjapõder noorema tütre.

Külaskäigul. Taat külastas järjest tütreid. Vanem tütar keetis sööki kõhukelmest ja jalatsipealsetest (= kehv elu). Keskmine tütar tegi igasuguseid kalaroogi. Üksnes noorem tütar valmistas liharoogi. Tal oli kaks last (põhjapõdravasikat).

Lahkumine naise ja laste juurest. Tütar riputas taadi asemeks pandud naha päikese kätte kuivama. Põhjapõder põgenes koos oma lastega.

Ema reageering. Ema tahtis lastele tissi anda, kuid need keeldusid. Ta hoiatas lapsi küti eest. Ema võttis koja koost lahti, et mujale rännata.

Põhjapõdrakoda. Koja latid olid sääreluudest, uks rinnakust, skeletiks roided, pealt kaetud nahkadega.

b) "Skazka pro zhenshchinu i dikogo olenja". Georgi Kert, $1955<<$ Maria Antonova (1900). Kildin, Teriberka. Avaldatud vene keeles Voskobojnikov, Menovshchikov 1959: 27--28; Sangi 1985: 13--16.

See on tedaolevalt ainuke jutt, mis on kaks korda aastase vaheajaga noteeritud samalt vestjalt, tõsi küll, esimesel juhul üliõpilasest tütre vahendusel.

Edastame loo algusosa:

Kaaren tuli ja võttis naiseks taadi vanema tütre. Hiljem tuli hüljes ja võttis naiseks taadi keskmise tütre. Möödus mõni aeg ja põhjapõder tuli nooremat tütart naiseks võtma. Nii läksidki kõik kolm tütart mehele: üks kaarnale, teine hülgele, kolmas põhjapõdrale. Vaat taadike elas, elas ja läks vanemale tütrele külla. Astus, astus ja näeb: koja kohal lendavad kaks kaarnapoega ja kraaksuvad:

Kronk, kronk, kronk, vanaisa tuleb,

Kronk, kronk, kronk, vanaisa tuleb,

Kronk, kronk, kronk, vanaisa tuleb.

Seda nad teatasid oma emale. Taadike astus kotta.

Tütar valmistas head-paremat. Ent millega kaaren saab kostitada: kõhukelme ja toberkipealsetega $* 21$. Taadike ei tea, mida sü̈̈a. Istus, istus ja asus teele keskmise tütre poole.

Jõudis lähemale, näeb, et kaks hülgepoega lasevad koja pealt liugu ja karjuvad:

Hur'gg, hur'gg, hur'gg, vanaisa tuleb,

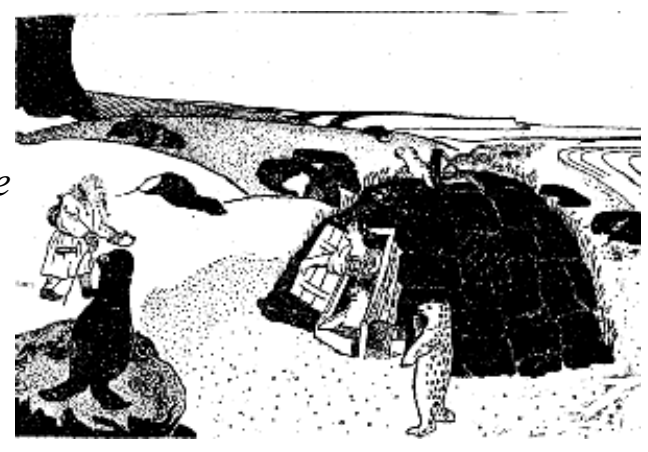

Hur'gg, hur'gg, hur'gg, vanaisa tuleb,

Hur'gg, hur'gg, hur'gg, vanaisa tuleb.

Taadike astus kotta. Tütar hakkas sü̈̈a tegema. Hülge kostitus on lõheriismed ja igat sorti kalatükid, kuid see on parem kui kaarnal. Taadike magas siin teise öö ja läks kolmandal 
päeval külla oma nooremale tütrele. Astus, astus ja näeb koda. Teisel pool koda jooksevad kaks põhjapõdravasikat: kaheaastane ja üheaastane. Üks käib kolmandat eluaastat, teine teist. Mängivad teisel pool koda koorunud sarvedega. Nägid vanaisa tulemas, jooksid koja ette ja karjuvad:

Honker, honker, vanaisa tuleb, Honker, honker, vanaisa tuleb.

Jooksevad lauluga mööda, nii et maa müdiseb.

Taadike astus kotta, põhjapõdravasikate ema hakkas süüa tegema: liha praadima ja keetma. Kojal on kaks ust: ühest käib põhjapõder, teisest perenaine [...] Taadike sõi ja jõi, sõi ja jõi ning heitis asemele, mille oli teinud tütar [...]"

See teisend on küllaltki tüüpiline. Kosimismotiiv on esitatud napisõnaliselt. Huvipakkuv on maining, et põhjapõder kasutas üht, tema abikaasa aga teist ust. Saami kotta tõi kütt oma saagi tagumise ukse (poashsh-uks, ka veerr-lõpps, s.o vereuks) kaudu, seejärel sisenes ta elamusse eesukse kaudu (Tsharnoluski 1966: 307). Ka turgi rahvastel ei tooda võõra maailma saadusi (jahinoosi) eesukse kaudu (Tradicionnoe mirovozzrenie 1988: 70), sest muidu tekib sel puhul opositsioon kultuurse ja loodusliku vahel. Meie loo põhjapõder on üheaegselt jahimees ja saak, sest ta kütib endataolisi. Põhjapõdrarahva meelest on muidugi kõige õnnelikum elu neil, kelle esivanemaks on põhjapõder ja kelle söögilaual on pidevalt liharoad.

Vahetult M. Antonovalt üles kirjutatud teisend erineb vaid kolme detaili poolest: 1) kolm tegelast tulid kosja k o r r a g a, 2) taat tegi neile ülesandeks valmistada kolm nikerdatud kappa, millega asjaosalised tulid toime ning 3) kaarnal oli söögiks rupskid ja pead. Viimase täienduse tegija pole selge (selleks võis ju olla ka toimetaja, kuna jalatsitepealsed ei tundunud pasliku toiduna). Kosilaste ilmumine ühekorraga esineb veel XVI jutus ning kappade valmistamine XIV jutus (vt); mõlemad on turja lood.

\section{Kümnes jutt}

"Tjulenji lasty". G. Kert, 1959 < Agrafena Arhipova (1903). Kildin. Lujaur. Avaldatud saami ja vene keeles Kert 1961:79-81; 1980:218-219 nr 136.

Naisevõtt. Eit nägi unes kaarnanokka, hülgeloibi ja põhjapõdra sõrgu, mida taat pidas kosilaste endeks. Pühapäeval läksid tütred metsa ega naasnud enam koju: nad olid mehele läinud.

Külaskäigul. Taati-eite külastasid tütreid. Vanemal tütrel oli kaaren teise silma peast välja nokkinud. Keskmise tütre kojas vedeles palju kalu. Taati-eite jäid põhjapõdra perre ööseks.

Põhjapõdrakoda. Põhjapõdral oli koda ehitatud luudest ja nahkadest.

Lahkumine naise ja laste juurest. Hommikul pani eit tütre keelust hoolimata asemenaha kuivama põhjapõdra teerajale. See põgenes koos pojaga.

Ema reageering. Ema tahtis pojale tissi anda, kuid see keeldus ja lõi koja puruks. Ema hoiatas poega ohtude eest.

Vanemate kojutulek. Eite-taati naasesid koju.

Ka see on kildini lugu, mis erineb eelmisest vaid üksikasjade poolest. Suhtumine võõrastesse, eriti kaarnasse on, nagu eelmiseski loos, vaenulik. Selles teisendis on rõhutatud unenäoennete tähtsust. Eit nägi unes vaid loomade (tootemite) kõige iseloomulikumaid kehaosi. Unenägu pole tähenduselt 
igapäevane, vaid pprohvetlik, nähtud laste abiellumise eel. Erinevalt eelmisest teisendist toimub kosimine märkamatult, mis võib tuleneda ehk jutustaja mäluviperustest.

Põhjapõdra luudest ja nahkadest koda on ilmselt sarnane esimese alatüübi põhjapõdrakojaga. Näib, et abielueelne kojaehitusmotiiv on ununenud ning see on esitatud joonena, mis peab põhjapõdra teistest kosilastest paremaks muutma.

\section{Üheteistkümnes jutt}

A. Genetz, $1876<$ ?. Turja, Jovkõj. Avaldatud Genetz 1878: 330 (lühikokkuvõte, märksõnade Mintõsh ja Meantash-ajk all); 1879a: 11; 1879b: 145-146 (saami keeles), 1891: 241-242, 279-280 (saami ja soome keeles).

Naisevõtt. Kaaren, hüljes ja põhjapõder kosisid inimeseks moondunult vastavalt taadi-eide vanema, keskmise ja noorema tütre. Eit lausub taadile järjepannu "kaarna tiivad paistavad", "hülge loivad paistavad", "põhjapõdra sarved paistavad".

Külaskäigul. Taat külastas tütreid. Vanemal tütrel oli kaaren silma peast välja nokkinud. Tütar peletas taati minema, et muidu kaaren pistab ta nahka. Keskmisel tütrel oli hüljes sõrmed ära närinud ning ta hoiatas, et taat läheks koju tagasi, muidu pistetakse ta nahka. Hülgelapsed kelgutasid väljas. Ainult noorem tütar elas põhjapõdraga õnnelikult. Taati nähes hõikasid põhjapõdralapsed rõõmsalt. Õhtul tuli põhjapõder koju ja muutus inimeseks. Ta andis taadile kaasa liha jm kosti.

Vanemate kojujõudmine. Taat tuli koju ja ladus kosti välja. Eit tahtis talt uudiseid teada.

On võimalik, et kõnealune lugu (vt $\underline{3}$, kus on esitatud kogu lugu tõlkes) on kildinlastele kulgenud turjalastelt. Nii kaarnat kui ka hüljest kujutati kurjaloomulistena: mõlemad olid oma abikaasa vigaseks teinud. Esmakordselt kohtame tõika, et kõik kosilased evisid inimeseks moondumise võimet. See kujutelm seondub, nagu eelnevalt käsitletud, totemismi ja shamanismiga.

Läheb edasi...

\section{Jooniste allkirjad}

9. 2,5-meetrine saarmakujutis Besi põhjaneemikult Äänisjärve noorema kiviaja kaljuraiendite leiukohast.

10. Saami jutuvestja Pjotr Sarvanov. V. Tsharnoluski joonistus.

11. Ülipikakaelalisi luigekujutisi Peri neemelt Äänisjärve noorema kiviaja kaljuraiendite leiukohast.

12. Saami kammed. V. Tsharnoluski joonistus.

13. Kaarnast väimees. V. Tsharnoluski joonistus.

14. Põhjapõdramäng. (Avaldan tänu ja Vladimir Shumkinile Materiaalse Kultuuri Uurimise Instituudist (Peterburi) ja Väino Poikalainenile Eesti Muinastaideseltsist selle muretsemise eest). 15. Hülgest väimees. V. Tsharnoluski joonistus. 


\section{Kirjandus}

(lisaks eelmises numbris avaldatule)

Ernits, E. 1990. Loomohver ja tulevikumärgid: Etüüd anatoomia seosest mantikaga. Eesti Loomaarstlik Ringvaade, nr 4,. 19-24.

Itkonen, T. I. 1946. Heidnische Religion und späterer Aberglaube bei den finnischen Lappen.

Helsinki (Suomalais-ugrilaisen seuran toimitteita, 87).

Kosmenko, A. P. 1993. Narodnoje izobrazitel'noje iskusstvo saamov Kol'skogo poluostrova XIXXX vv.: Etnografitsheski otsherk. Petrozavodsk.

Kostjuhhin, E. A. 1987. Tipy i formy zhivotnogo eposa. Moskva.

Krohn, K. 1906. Lappische Beiträge zur germanischen Mythologie. Finnisch-ugrische

Forschungen. Bd. 6, 104-111.

Leem, K. 1771. Nachrichten von den Lappen in Finmarken, ihrer Sprache, Sitten, Gebräuche und ehemahligen heidnischen Religion. Leipzig.

Lehtisalo, T. 1934. Lepästä sielupuuna suomensukuisilla kansoilla. Kalevalaseuran vuosikirja, 14. Porvoo-Helsinki, 76- 83.

Lönnrot, E. 1958. Kalevala. Tõlkinud A. Annist. Tallinn.

Meletinski, J. M. 1979. Paleoaziatski mifologitsheski epos: Tsikl vorona. Moskva.

Paulson, I. 1958. Die primitiven Seelenvorstellungen der nordeurasischen Völker: Eine religionsethnographische und religionsphänomenologische Untersuchung. Stockholm.

Sangi, V. M. 1985. Legendy i mify Severa. Moskva (Biblioteka literatur narodnostej Severa i Dal'nego Vostoka).

Tradicionnoje mirovozzrenije tjurkov Juzhnoj Sibiri: Prostranstvo i vremja. Veshtshnyj mir. Novosibirsk 1988.

Tradicionnoje mirovozzrenie tjurkov Juzhnoj Sibiri: Znak i ritual. Novosibirsk 1990.

Turunen, A. 1981. Kalevalan sanat ja niiden taustat. Helsinki.

Viires, A. 1975. Puud ja inimesed: Puude osast Eesti rahvakultuuris. Tallinn.

Voskobojnikov, M. G., Menovshchikov, G. A. 1959. Skazki narodov Severa. Moskva, Leningrad.

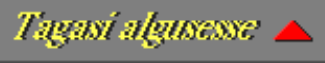




\section{Kommentaarid}

15 Lõvt (saami lõvv't, ka luutt) - kindlate sõnadeta saami rahvalaul; V. Tsharnoluski raamatutes enamasti muinasloo tähenduses.

16 Kamme (saami koamme, kaamga, kaammi) - nahast suvejalats ülespoole nööride ja käänatud ninadega; kaunistatud valge naha ja värvilise kaleviga.

17 Tonk-puoid (saami tonnk, togg 'umbsool; libedik'; pöiit, puuiit, põiite 'rasv') - umbsooles või libedikus säilitatav rasv.

18 Peit'-oll'ke - V. Tsharnoluskil ilmselt vääriti kuuldud või tõlgitud sõnaühend (vrd. saami pett 'naiste sääris'; ol'ke, olgõj 'kate').

19 Tsheäppat (saami tsheäppat) - kael (vrd eesti seba, soome reen sevät 'ree kaarduv esiosa').

20 Jall' voai (saami jiel'l'e vuoije $(m)$ ) - elada võin.

21 Toberkid (saami tobärk, tubõrk) - põhjapõdranahast õmmeldud jalatsid. 